\title{
Credit of peanut to subsequent wheat under desert farming conditions in presence of diazotrophs and nitrogen fertilizers
}

\author{
Badawi, H. Mona; Fayez, M.
}

Department of Microbiology, Faculty of Agriculture, Cairo University 12613, Giza, Egypt

\begin{abstract}
Rotation with leguminous crops to break nonlegume monocultures has been established to benefit the latter. The lacking information on this cultivation system in stressed environments encouraged the implementation of two field trials in two different locations of Ismailia desert soils. The experimental design included the cultivation of wheat subsequent to peanut in presence of diazotroph inoculation and $N$ fertilization. Bradyrhizobial inoculation of the legume in combination with $50 \mathrm{~kg} \mathrm{~N} \mathrm{acre}{ }^{-1}$ resulted in the highest total biological yields of 4.24 and $5.01 \mathrm{~kg}$ plot $^{-1}$ at the experimental sites 1 and 2, respective seed yields of 1.46 and $1.61 \mathrm{~kg} \mathrm{pot}^{-1}$ were recorded. In case of the cereal crop, the measured acetylene reducing activities in soils of associative diazotroph-inoculated plants together with $50 \mathrm{~kg} \mathrm{~N}$ acre-1 were the highest being 515.8886.2 and 616.7-1066.2 nmoles $\mathrm{C}_{2} \mathrm{H}_{4} \mathrm{~g}^{-1} h^{-1}$ at locations 1 and 2 respectively. The enzymatic activity of fallowcultivated wheat generally represented ca. $95 \%$ of that in subsequent to peanut. Irrespective of inoculation and $N$ fertilization, the wheat biomass yield increases in residual effect-field over the fallow one were 6.4-35.1\% and 4.6$38.5 \%$ at experimental sites 1 and 2 respectively. Increase percentages of 3.1-26.6 and 6.9-44.7 were scored as well for grain yield. The beneficial residual effect of the legume to the succeeding cereal was also extended to protein yields, increases of 4.0-14.2 \% and 4.5-7.6 \% were estimated for grain protein as well as 8.3-24.1\% and 8.1$35.3 \%$ for straw protein yield. The findings of this study proved that the positively yield turnover of a legume is extended to the subsequent non-legume. Besides, the beneficial residual effects of legumes toward rotated non legumes could be magnified by diazotroph inoculation together with adequate $N$ supply particularly in stressed environments represented, in the present study, by Ismailia sandy soil.
\end{abstract}

Keywords - Peanut, wheat, diazotroph inoculation, $N$ fertilization, residual effect, crop yield.

\section{INTRODUCTION}

In 2050, the global population is expected to hit 9.6 billion people (UNWPP, 2013). This will certainly meet a number of challenges where restricting the risks of climate change as a result of releasing greenhouse gases into the atmosphere, achieving food security and satisfying the needs for energy are representing the most critical ones (Stagnari et al., 2017).

To face these challenges, the development of a policy framework seems to be compulsory in which the sustainability of production, consumption patterns are being central. In this respect, food legumes are obviously contributing in delivering a number of multiple services in live with sustainability principles. In fact, leguminous plants are having 3 major central roles, those are 1) at foodsystem level, they are a good source of protein for both human and animal consumption, 2) at production-system level, they are potentially unavoidable for inclusion in lowinput cropping systems due to their capability to save a sufficient $\mathrm{N}$ pool via $\mathrm{N}_{2}$-fixation with rhizobia and 3) at cropping-system level, for breaking the cycles of pests and diseases (Jensen et al., 2010; Kopke and Nemecek, 2010; Westhoek et al., 2011). Indeed, the role played by legumes towards $\mathrm{N}$ budget in cereal-based cropping systems is well documented. Although cereals are prominent source of carbohydrates for humans and animals, their continuous cultivation negatively reflects on soil fertility. For example, and as mentioned by Zou et al. (2015), up to $70 \%$ loss of total $\mathrm{N}$ was scored in sandy soil in Australia after 70 years of continuous cereal cultivation and production.

In this context, it should be realized that, among the major yield limiting factors for cereals, nitrogen deficiency occupies a non-tiny place. Due to their nonavailability at proper times, low economic conditions of farmers and high costs, the use of nitrogenous fertilizers in Egypt is relatively low. Here, the inclusion of leguminous crops, known to enrich the soil with nitrogen via nitrogen fixation, in crop rotations is necessary. In such crop 
rotations, a great part of legume $\mathrm{N}$ symbiotically fixed by rhizobia comes available for the subsequent non-legume via decomposition and mineralization of the legume residues. These residues are characterized by their high $\mathrm{N}$ contents and narrow $\mathrm{C} / \mathrm{N}$ ratios compared to those of cereal crops. As mentioned by Hayat et al. (2008), the crop residues incorporated into soil are initially exposed to microbial attack resulting in their conversion into new products which improve soil physico-chemical activities, restore organic matter pool besides having smothering effects towards weeds.

Compared to monocultured cereals, those cropped in sequence with legumes drive $\mathrm{N}$ benefits. In continued cereal cultivation, $\mathrm{N}$ fertilization should be supplemented in rotation systems using legume break crops to guarantee supply and availability of N (Mohd-Radzman et al., 2013). The $\mathrm{N}$ gain to non-legumes in legume-cereal rotations is entirely due to the release and transfer of biologically fixed $\mathrm{N}$. The decomposition of legume residues along the postharvest fallow period that precede the non-legume might interpretate the differences in the contribution of fixed $\mathrm{N}$ to the element budget of intercropped and rotation systems (Peoples and Herridge, 1990). However, it has to be considered that the improvement in nitrogen nutrition of non-fixing crops in the grain legume-based cultivation patterns needs more understanding of the processes of legume residues decomposition in soil beside the interactions with soil organic matter. Actually, the species and varieties of the leguminous plants growing at the same location conspicuously differ in biomass production, $\mathrm{N}_{2}$ fixation, $\mathrm{N}$ content, $\mathrm{N}$-net gain in addition to the quality of residues (Evans et al., 2001). All of such differences represent the key factors that govern the contribution of the residual $\mathrm{N}$ to subsequent cereal crop.

In view of the important role legume plants can play in maintaining soil productivity that obviously reflects on the succeeding cereal development and yield, two rotational field trials were implemented in the present study on peanut during summer seasons of 2015 and 2016 followed by wheat in each year. This is in an attempt to assess nitrogen fixation by the legume and its residual effects on yield production of the succeeding non-legume cultivated under stressed environments of Ismailia desert soils.

\section{MATERIALS AND METHODS}

\section{Experimental sites}

Two field trials were conducted at neighboring sites in sandy soils@ Ismailia governorate. Representative soil samples were collected from both locations and analyzed for mechanical and physico-chemical properties (Table 1) using the procedures of Chapman and Pratt (1978). The meteorological data including the mean monthly temperature and rainfall records during the experimental period extended from May 2015 to April 2017 are illustrated in Figure (1).

Table.1: Mechanical and physico-chemical properties of soil samples taken from experimental sites @ Ismailia

\begin{tabular}{|c|c|c|}
\hline Properties & Site 1 (Trial 1) & Site 2 (Trial 2) \\
\hline Coarse sand (\%) & 61.2 & 41.2 \\
\hline Fine sand $(\%)$ & 29.1 & 45.4 \\
\hline Silt $(\%)$ & 4.3 & 4.3 \\
\hline Clay $(\%)$ & 3.2 & 6.1 \\
\hline Calcium carbonate $(\%)$ & 2.9 & 3.8 \\
\hline Textural class & Sandy & Sandy loam \\
\hline Saturation $(\%)$ & 19.1 & 22.2 \\
\hline Water holding capacity (\%) & 11.8 & 18.3 \\
\hline $\mathrm{pH}$ & 7.9 & 7.2 \\
\hline $\mathrm{EC}\left(\mathrm{dSm}^{-1}\right)$ & 0.93 & 0.81 \\
\hline Organic matter $(\%)$ & 0.40 & 0.68 \\
\hline Total nitrogen $(\%)$ & 0.016 & 0.021 \\
\hline \multicolumn{3}{|l|}{ Cations (meq $\mathrm{l}^{-1}$ ) } \\
\hline $\mathrm{Ca}^{++}$ & 2.17 & 5.01 \\
\hline $\mathrm{Mg}^{++}$ & 1.09 & 3.46 \\
\hline $\mathrm{Na}^{+}$ & 1.22 & 2.99 \\
\hline $\mathrm{K}^{+}$ & 0.61 & 2.15 \\
\hline \multicolumn{3}{|l|}{$\underline{\text { Anions }\left(\text { meq } 1^{-1}\right)}$} \\
\hline $\mathrm{SO}_{4}^{--}$ & 1.47 & 7.36 \\
\hline $\mathrm{Cl}^{-}$ & 1.01 & 3.68 \\
\hline $\mathrm{HCO}_{3}{ }^{-}$ & 2.61 & 2.57 \\
\hline
\end{tabular}




\section{포 Temperature ${ }^{\circ} \mathrm{C} \quad$ Q Rainfall $(\mathrm{mm})$}

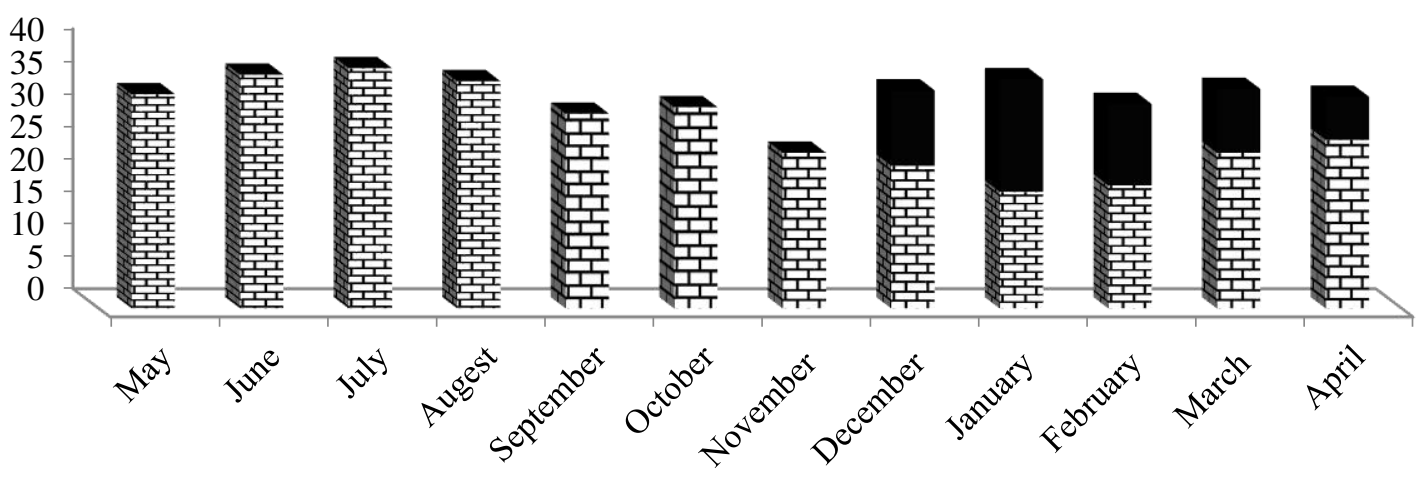

Growing seasons

Fig.1. Average records of temperature and rainfall from May 2015 to April 2017 at the experimental areas.

\section{Host plants}

Seeds of peanut (Arachis hypogaea L.) cv. Giza 5, and wheat (Triticum aestivium L.) cv. Sakha 94 were kindly provided by Crop Research Institute, Agricultural Research Center (ARC), Giza.

Diazotroph inocula preparation and application

One Bradyrhizobium spp. isolate specific for peanut obtained from the Department of Agricultural Microbiology; Soils, Water and Environmental Research Institute, ARC, Giza, in addition to both Azospirillum brasilense and Azotobacter chroococcum strains isolated by Badawi (2014) were the used diazotroph inocula. For legume inoculant preparation, the broth culture of Bradyrhizobium spp. was mixed with neutralized fine peat $(\mathrm{pH} 7.0)$ as a carrier material at the rate of $2: 1(\mathrm{v} / \mathrm{w})$ to guarantee an inoculum density of $c a .10^{9}$ cells $\mathrm{g}^{-1}$. This diazotroph formulation was used as seed inoculant @ the rate of $5 \mathrm{~g}$ inoculant $/ 100 \mathrm{~g}$ seeds using Arabic gum as adhesive material. In case of associative diazotrophs, equal portions of either Azospirillum or Azotobacter ( $\mathrm{ca} .10^{8}$ cells $\mathrm{ml}^{-1}$ ) were thoroughly mixed and used as a composite inoculum. Cereal seeds were soaked in the diazotroph mixture for $30 \mathrm{~min}$. just prior to planting.

\section{NPK fertilization regimes}

After land preparation, the PK fertilization regimes recommended for peanut cultivation were applied, those represented by superphosphate $\left(\mathrm{P}_{2} \mathrm{O}_{5}, 15 \%\right)$ and potassium sulphate $\left(\mathrm{K}_{2} \mathrm{O}, 48 \%\right)$ incorporated into soil in quantities equivalent to 200 and $50 \mathrm{~kg} \mathrm{acre}^{-1}$ respectively. Besides, urea (N, $46 \%$ ) was added at rates of 20 and $50 \mathrm{~kg}$ $\mathrm{N}$ acre $^{-1}$. For wheat, superphosphate and potassium sulphate were added at respective amounts equivalent to 150 and $50 \mathrm{~kg} \mathrm{acre}^{-1}$. Urea was added at the recommended rate of $100 \mathrm{~kg} \mathrm{acre}^{-1}$ and its half in two equal splits at sowing and after 30 days of sward establishment.

\section{Experimental layout}

Two rotational field trials were executed on peanut during the summer seasons (2015 and 2016) followed by wheat in each year at two neighboring locations of sandy soil at Ismailia governorate to monitor the residual effects of the legume plant on the subsequent cereal yield. Each field trial was executed in a randomized complete block design with 4 replicates in a net plot size of $2.0 \times 2.5 \mathrm{~m}$. In location (1), seeds of peanut were sown on 28-5-2015 at a rate equivalent to $50 \mathrm{~kg} \mathrm{acre}^{-1}$. In a neighboring site, a similar land area was kept fallow. In both sites of location (1), wheat grains were sown on 1411-2015 at a seeding rate equivalent to $70 \mathrm{~kg} \mathrm{acre}{ }^{-1}$. Treatments allocated for the legume were 1) uninoculatedunfertilized, 2) inoculated-unfertilized, 3) uninoculated + $20 \mathrm{~kg} \mathrm{~N} \mathrm{acre}{ }^{-1}$, 4) inoculated $+20 \mathrm{~kg} \mathrm{~N} \mathrm{acre}{ }^{-1}$, 5) uninoculated $+50 \mathrm{~kg} \mathrm{~N}$ acre $^{-1}$ and 6) inoculated $+50 \mathrm{~kg} \mathrm{~N}$ $\mathrm{acre}^{-1}$. For the non-legume, the following were the applied treatments: 1) uninoculated-unfertilized, 2) inoculatedunfertilized, 3) uninoculated $+50 \mathrm{~kg} \mathrm{~N}$ acre $^{-1}$, 4) inoculated $\left.+50 \mathrm{~kg} \mathrm{~N} \mathrm{acre}^{-1}, 5\right)$ uninoculated $+100 \mathrm{~kg} \mathrm{~N} \mathrm{acre}^{-1}$ and 6) inoculated $+100 \mathrm{~kg} \mathrm{~N}$ acre $^{-1}$. In location (2), the peanutwheat rotating experiment of seasons 2015-2016 was repeated in summer-winter seasons of 2016-2017 with the same previously applied inoculation and $\mathrm{N}$ fertilization treatments.

\section{Sampling and determinations}


Sampling was done twice, at the $60^{\text {th }}$ and $90^{\text {th }}$ days of planting. Top $(0-30 \mathrm{~cm})$ soil samples were taken from four random points within each plot and thoroughly mixed to obtain a representative sample for each replicate. Plant samples were collected from the middle of plots without tearing the root system as possible and the root system of the legume plant was separated. Determinations were the following:

\section{Microbiological}

Nitrogenase activities of soils and the nodulated peanut root systems were estimated by acetylene reduction assay (ARA) using gas chromatograph adopting the method of Hegazi et al. (1980).

\section{Agronomical}

The following parameters were estimated during the growing seasons 1) number and dry weights of nodules formed on root systems of the legume plant at the $60^{\text {th }}$ and $90^{\text {th }}$ days, and 2) at harvest, total biological and seed yields were determined for both tested crops.

\section{Chemical}

Total nitrogen contents of seeds and straw were estimated using the semi-micro-Kjeldahl method (Bremner, 1965).

\section{Statistical analysis}

Results were computed using analysis of variance (ANOVA) (Huang and Chen, 2008). Least significant differences (LSDs) were calculated from ANOVA tables.

\section{RESULTS}

Nodulation of the leguminous plant (Fig. 2) was among the criteria that obviously affected by the applied treatments. Untreated peanuts bore the lowest number of root nodules (36-69 per plant) of the lowest dry weights (92.4-174.7 mg plant $^{-1}$ ). Bradyrhizobium-inoculated plants hosted more nodules on their root systems, an effect that was $\mathrm{N}$ level-dependent. While the rational $\mathrm{N}$ fertilizer regime $\left(20 \mathrm{~kg} \mathrm{acre}^{-1}\right)$ supported higher nodule formation by inoculated plants (186-269 nodules plant ${ }^{-1}$, 425.6-619.5 mg plant $^{-1}$ ), heavy $\mathrm{N}$ dressing $\left(50 \mathrm{~kg} \mathrm{acre}^{-1}\right.$ ) had relatively deleterious effects on nodule production (89-156 nodules plant $^{-1}$, 212.0-378.4 mg plant $\left.{ }^{-1}\right)$. In general, location 2 seemed more favorable for the legume nodulation than location 1, average increase percentages of 9.7 and 14.8 were estimated for nodule numbers and dry weights respectively.

\section{Location 1 (2015)}

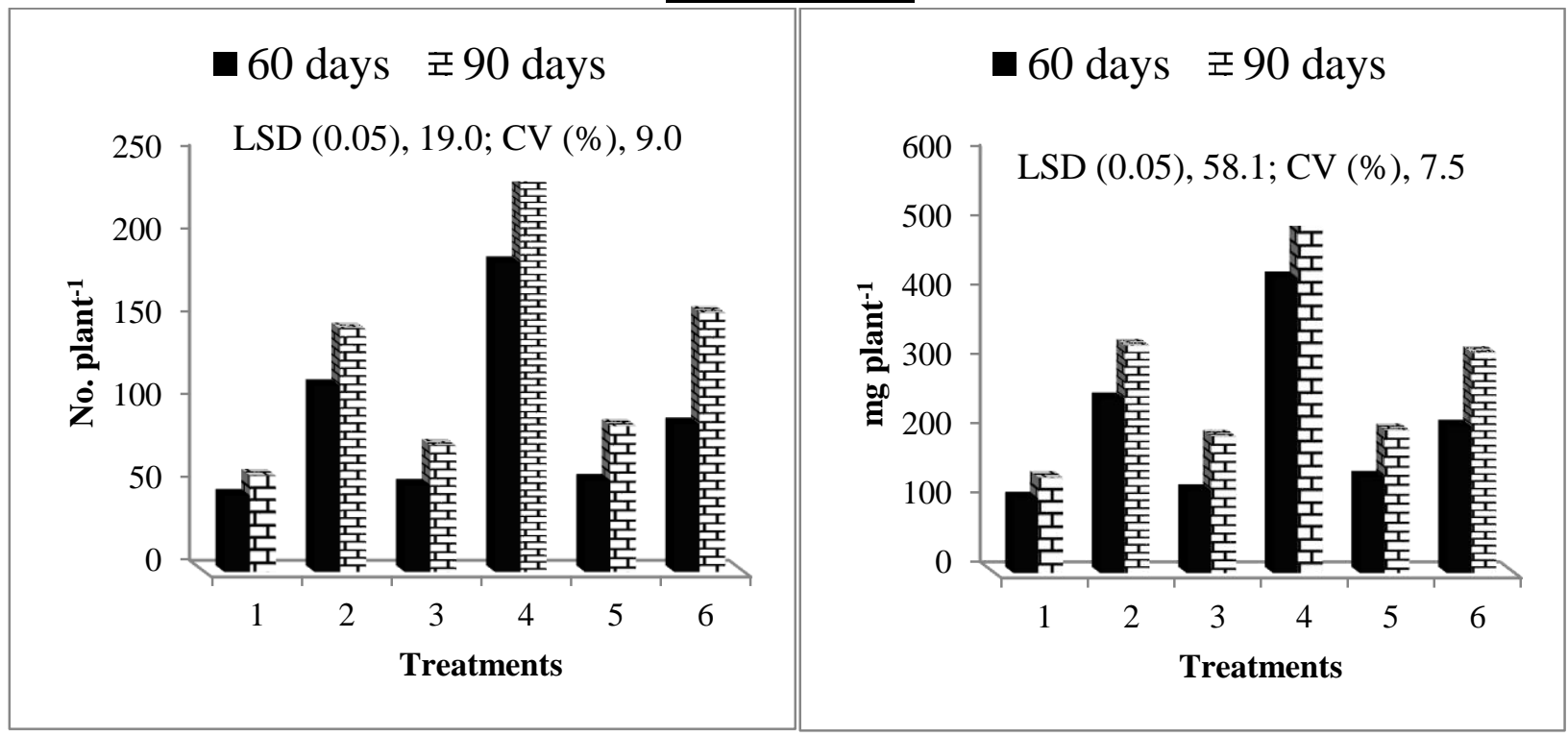




\section{Location 2 (2016)}

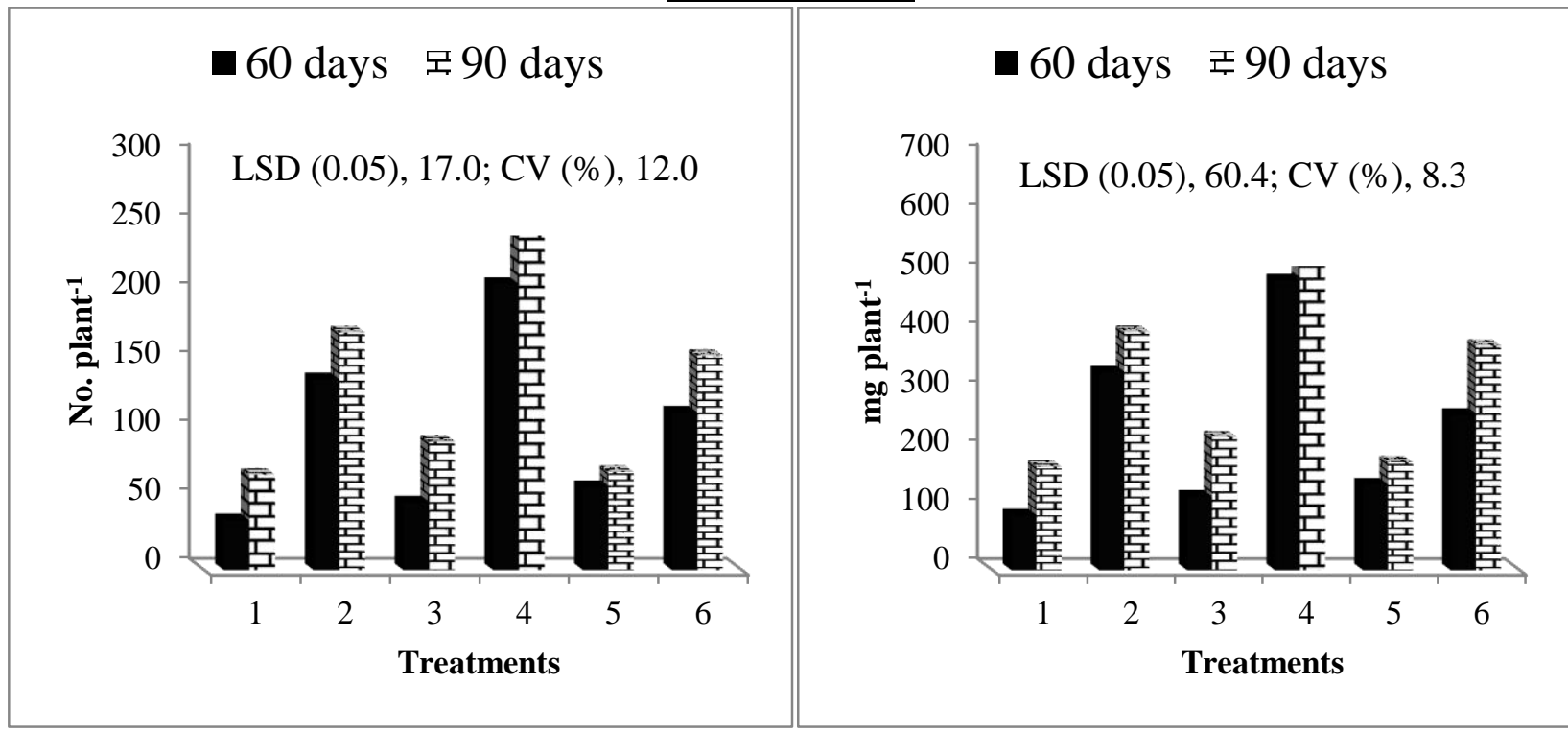

Fig.2: Numbers (per plant) and dry weights $\left(\mathrm{mg} \mathrm{plant}^{-1}\right)$ of peanut root nodules as affected by Bradyrhizobium inoculation and $\mathrm{N}$ fertilization. 1) uninoculated-unfertilized, 2) inoculated-unfertilized, 3) uninoculated $+20 \mathrm{~kg} \mathrm{Nacre}{ }^{-1}$, 4) inoculated $+20 \mathrm{~kg} \mathrm{~N}$ acre $^{-1}$, 5) uninoculated $+50 \mathrm{~kg} \mathrm{~N}$ acre ${ }^{-1}$ and 6) inoculated $+50 \mathrm{~kg} \mathrm{Nacre}^{-1}$.

Acetylene reducing activities of peanut root systems and soils of all the applied treatments proportionally increased with plant age (data not shown). Roots of uninoculated peans exhibited the lowest nitrogenase activities (Fig. 3) indicating that the autochthonous bradyrhizobia specific for the legume plant are existing in low population. Introduction of Bradyrhizobium spp. intensified, as expected, the enzymatic activity. Incorporation into soil of the rational $\mathrm{N}$ dose of $20 \mathrm{~kg} \mathrm{acre}^{-1}$ magnified the beneficial effect of inoculation recording the highest average activities of 407.8 and 495.1 nmoles $\mathrm{C}_{2} \mathrm{H}_{4} \mathrm{~g}^{-1} \mathrm{~h}^{-1}$ for plants cultivated in locations 1 and 2 respectively. Fertilization with $50 \mathrm{~kg} \mathrm{~N}$ acre ${ }^{-1}$ obviously decreased the activities even in presence of the diazotroph. Similarly, acetylene reducing activities in soil were treatment-dependent. Irrespective of location, activities hardly exceeding 200 nmoles $\mathrm{C}_{2} \mathrm{H}_{4} \mathrm{~g}^{-1} \mathrm{~h}^{-}$ ${ }^{1}$ were measured for soils of untreated peanuts. Storms of the enzymatic activities were estimated for inoculated and $20 \mathrm{~kg} \mathrm{~N}$ acre $^{-1}$ fertilized plants, being $>1650$ nmoles $\mathrm{C}_{2} \mathrm{H}_{4}$ $\mathrm{g}^{-1} \mathrm{~h}^{-1}$.

Untreated peanut plants produced the lowest total biological yields of 1.24 and $1.64 \mathrm{~kg} \mathrm{plot}^{-1}$ at experimental sites 1 (season 2015) and 2 (season 2016) respectively
(Table 2). Bradyrhizobial inoculation of unfertilized plants resulted in respective increases in biological yields approximated 26 and $23 \%$. Integration of diazotroph inoculation and $\mathrm{N}$ fertilization significantly intensified the legume biomass yields. As high as 4.24 and $5.01 \mathrm{~kg} \mathrm{plot}^{-1}$ dry weights were recorded for plants received $50 \mathrm{~kg} \mathrm{~N}$ acre 1 simultaneously with bradyrhizobial inoculation at the experimental locations 1 and 2 respectively. Comparatively lower total biological yields were attributed to $20 \mathrm{~kg} \mathrm{~N}$ fertilization regime even in presence of the diazotroph. Apart from the applied treatments, biomass yields of site 2cultivated peanuts overcame those grown in site 1 , the average increase percentage was 20.0.

The legume seed yield (Table 2) variably responded to inoculation and $\mathrm{N}$ fertilization treatments. While $50 \mathrm{~kg} \mathrm{~N}$ acre $^{-1}$ together with bradyrhizobial treatment supported the highest yields of 1.46 and $1.61 \mathrm{~kg}$ plot $^{-1}$ during 2015 and 2016 summer seasons respectively, significantly lower yields $\left(0.43\right.$ and $\left.0.59 \mathrm{~kg} \mathrm{plot}^{-1}\right)$ were produced by inoculated but not fertilized peanuts. This indicates the necessity of integrated inoculation and $\mathrm{N}$ supplement to secure the proper yield under rigorous conditions prevailing in the experimental area. 


\section{Location 1 도Location 2}
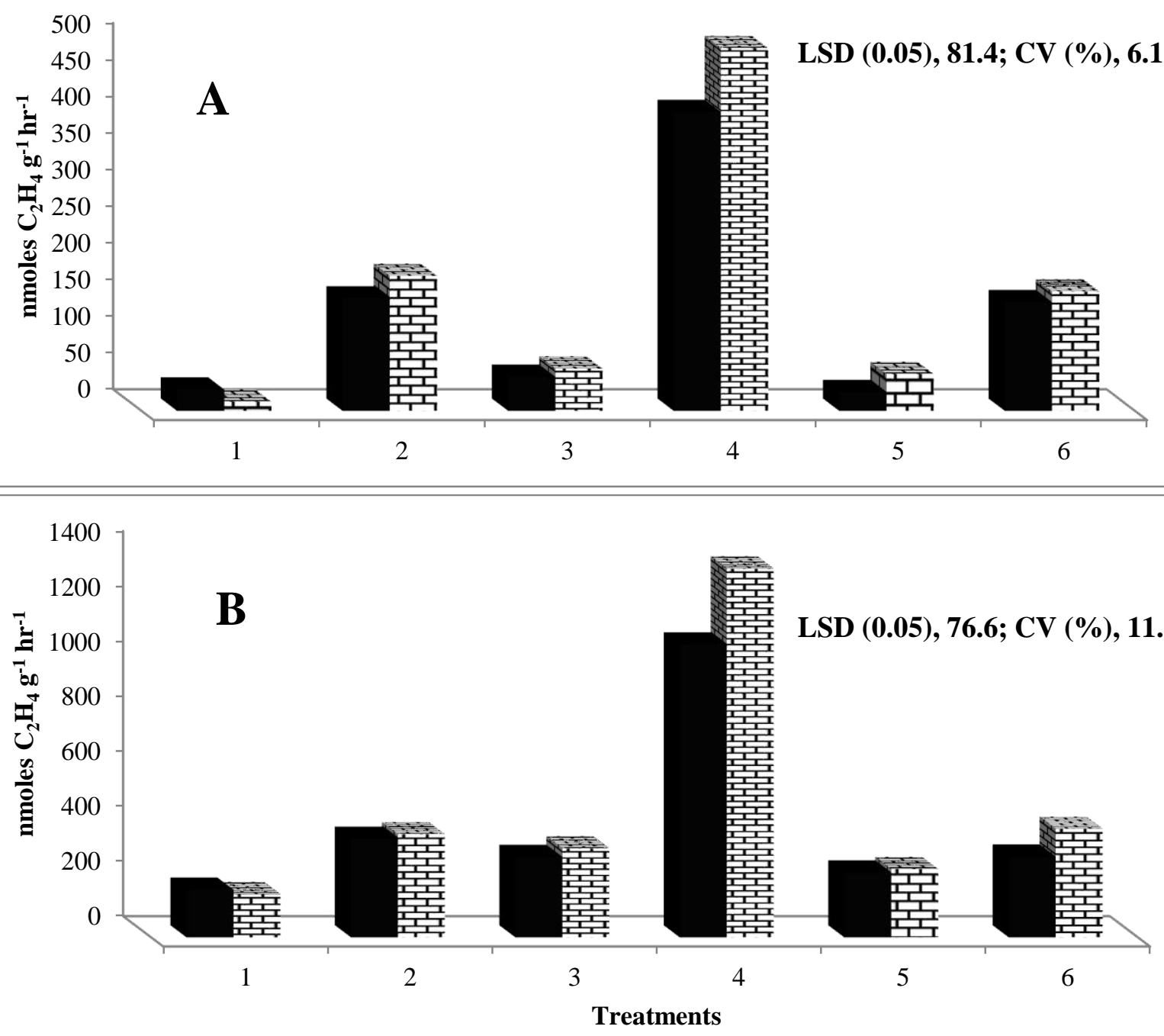

Fig.3: Acetylene reducing activities of root system (A) and soil (B) of peanuts as affected by inoculation with Bradyrhizobium spp. and N-fertilization: 1) uninoculated-unfertilized, 2) inoculated-unfertilized, 3) uninoculated+50 $\mathrm{kg} \mathrm{Nacre}{ }^{-1}$, 4) inoculated+ $50 \mathrm{~kg} \mathrm{~N}$ acre $\left.^{-1}, 5\right)$ uninoculated $+100 \mathrm{~kg} \mathrm{~N}$ acre $^{-1}$ and 6) inoculated $+100 \mathrm{~kg} \mathrm{Nacre}{ }^{-1}$. Data represent the averages of the $60^{\text {th }}$ and $90^{\text {th }}$ days measurements.

As expected, heavy $\mathrm{N}$ dressing at the rate of $50 \mathrm{~kg} \mathrm{~N}$ acre ${ }^{-1}$, even in absence of the diazotroph, accumulated the highest protein quantities in both seeds and straw (Table 2). Bradyrhizobial inoculation magnified the positive influence of $\mathrm{N}$ addition on protein production particularly with $50 \mathrm{~kg}$ $\mathrm{N}$ acre ${ }^{-1}$-received peanuts, a phenomenon recorded for both seeds and straw. The relatively higher fertility level of soil of location 2 compared to soil of location 1 conspicuously reflected on the various yield parameters of the legume plant. Irrespective of inoculation and $\mathrm{N}$ level, total biological and seed yields as well as seed and straw protein contents of peanuts cultivated in location 2 were 20.0, 7.4, 0.69 and $6.97 \%$ higher than those grown in soil of location 1.

Generally speaking, acetylene reducing activities in soils cultivated with wheat severely reduced when 100 $\mathrm{kg} \mathrm{N}$ acre $^{-1}$ were added (Fig. 4). In such soils, the activities decreased by 28.2 and $36.7 \%$ for locations 1 and 2 respectively. Dual culture of Azospirillum and Azotobacter, in absence of $\mathrm{N}$ supply, recorded respective increases of 346.4 and $306.4 \%$. Simultaneous diazotroph inoculation successfully overcame the detrimental impact of heavy $\mathrm{N}$ 
dressing on the enzyme activity beside recording increases of $c a .120$ and $93 \%$ for locations 1 and 2 respectively. The highest estimates of acetylene reduction were obtained for soils of inoculated-50 kg N acre ${ }^{-1}$-treated plants being 515.8-886.2 and 616.7-1066.2 nmoles $\mathrm{C}_{2} \mathrm{H}_{4} \quad \mathrm{~g}^{-1} \mathrm{hr}^{-1}$, respectively. Apart from treatment and experimental site, soils of fallow-cultivated wheat exhibited acetylene reducing activity representing $c a .95 \%$ of that in subsequent to peanut.

Table.2: Yield parameters of peanut plants of the different inoculation and $N$ fertilization treatments

\begin{tabular}{|c|c|c|c|c|}
\hline \multirow[t]{2}{*}{ Treatments } & \multirow{2}{*}{$\begin{array}{c}\text { Total biological } \\
\text { yield } \\
\left(\mathrm{kg} \mathrm{plot}^{-1}\right)\end{array}$} & \multirow{2}{*}{$\begin{array}{l}\text { Seed yield } \\
\left(\mathrm{kg} \mathrm{plot}^{-1}\right)\end{array}$} & \multicolumn{2}{|c|}{ Protein $(\%)$} \\
\hline & & & Seed & Straw \\
\hline \multirow{10}{*}{$\begin{array}{l}\text { Uninoculated-unfertilized } \\
\text { Inoculated-unfertilized } \\
\text { Uninoculated+ } 20 \mathrm{~kg} \mathrm{~N} \text { acre }^{-1} \\
\text { Inoculated+ } 20 \mathrm{~kg} \mathrm{~N} \mathrm{acre}{ }^{-1} \\
\text { Uninoculated+50 kg N acre } \text { acr }^{-1} \\
\text { Inoculated+50 kg N acre } \\
\text { LSD }(0.05) \\
\text { CV }(\%)\end{array}$} & \multicolumn{4}{|c|}{$\underline{\text { Location } 1 \text { (2015) }}$} \\
\hline & 1.24 & 0.34 & 26.4 & 10.8 \\
\hline & 1.56 & 0.43 & 27.9 & 12.6 \\
\hline & 1.95 & 0.66 & 28.3 & 11.2 \\
\hline & 2.17 & 0.85 & 29.1 & 13.7 \\
\hline & 3.86 & 1.11 & 28.0 & 11.7 \\
\hline & 4.24 & 1.46 & 33.8 & 14.9 \\
\hline & 0.11 & 0.09 & 2.7 & 1.9 \\
\hline & 13.4 & 9.2 & 18.9 & 10.7 \\
\hline & \multicolumn{4}{|c|}{ Location 2 (2016) } \\
\hline Uninoculated-unfertilized & 1.64 & 0.43 & 25.2 & 11.9 \\
\hline Inoculated-unfertilized & 2.01 & 0.59 & 28.7 & 11.7 \\
\hline Uninoculated $+20 \mathrm{~kg} \mathrm{~N}$ acre $^{-1}$ & 2.44 & 0.60 & 30.3 & 12.9 \\
\hline Inoculated +20 kg $N$ acre ${ }^{-1}$ & 2.74 & 0.98 & 27.9 & 14.0 \\
\hline Uninoculated $+50 \mathrm{~kg} \mathrm{~N}$ acre $^{-1}$ & 4.14 & 1.01 & 28.5 & 12.8 \\
\hline Inoculated+ 50 kg $\mathrm{N}$ acre ${ }^{-1}$ & 5.01 & 1.61 & 34.1 & 16.8 \\
\hline $\operatorname{LSD}(\mathbf{0 . 0 5})$ & 0.31 & 0.28 & 2.1 & 2.4 \\
\hline CV $(\%)$ & 16.3 & 9.2 & 12.3 & 8.3 \\
\hline
\end{tabular}

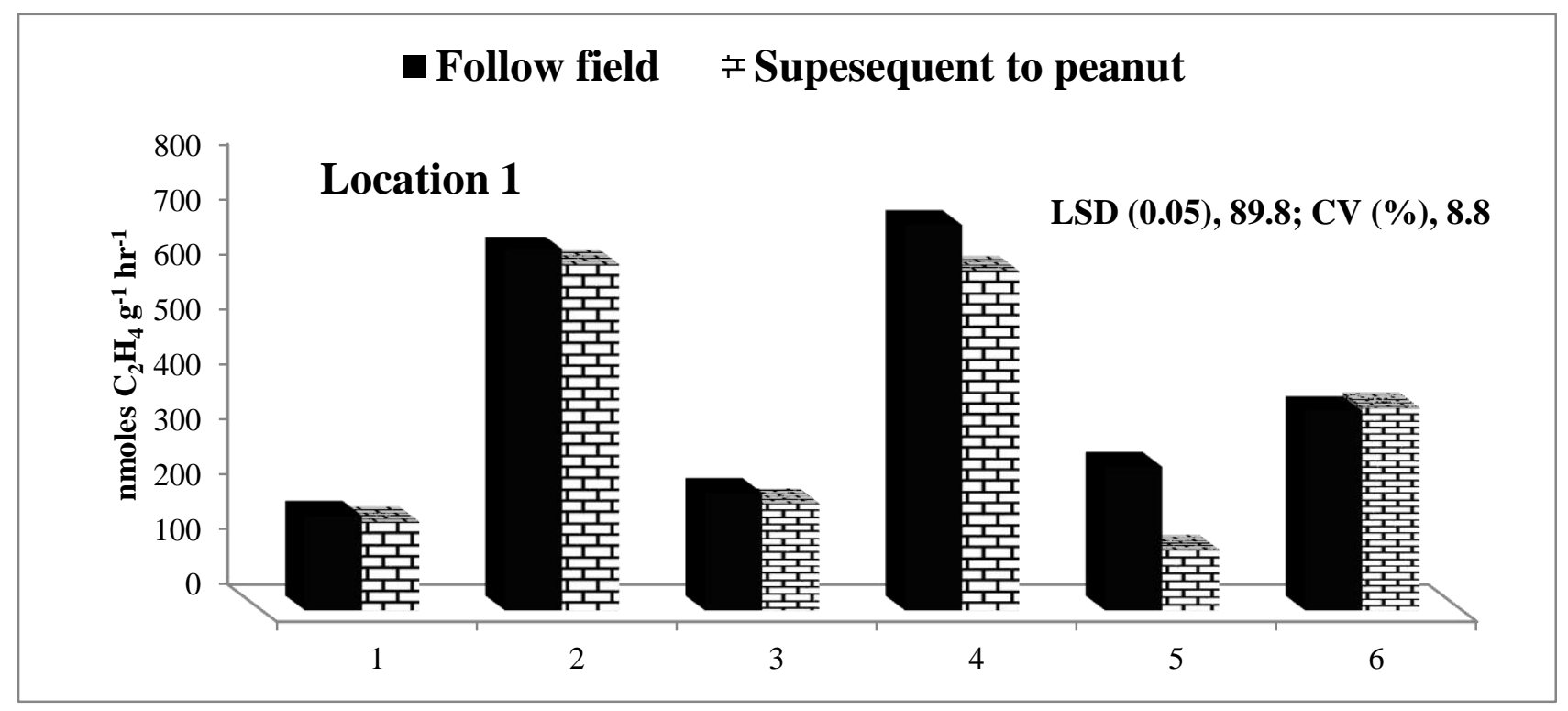




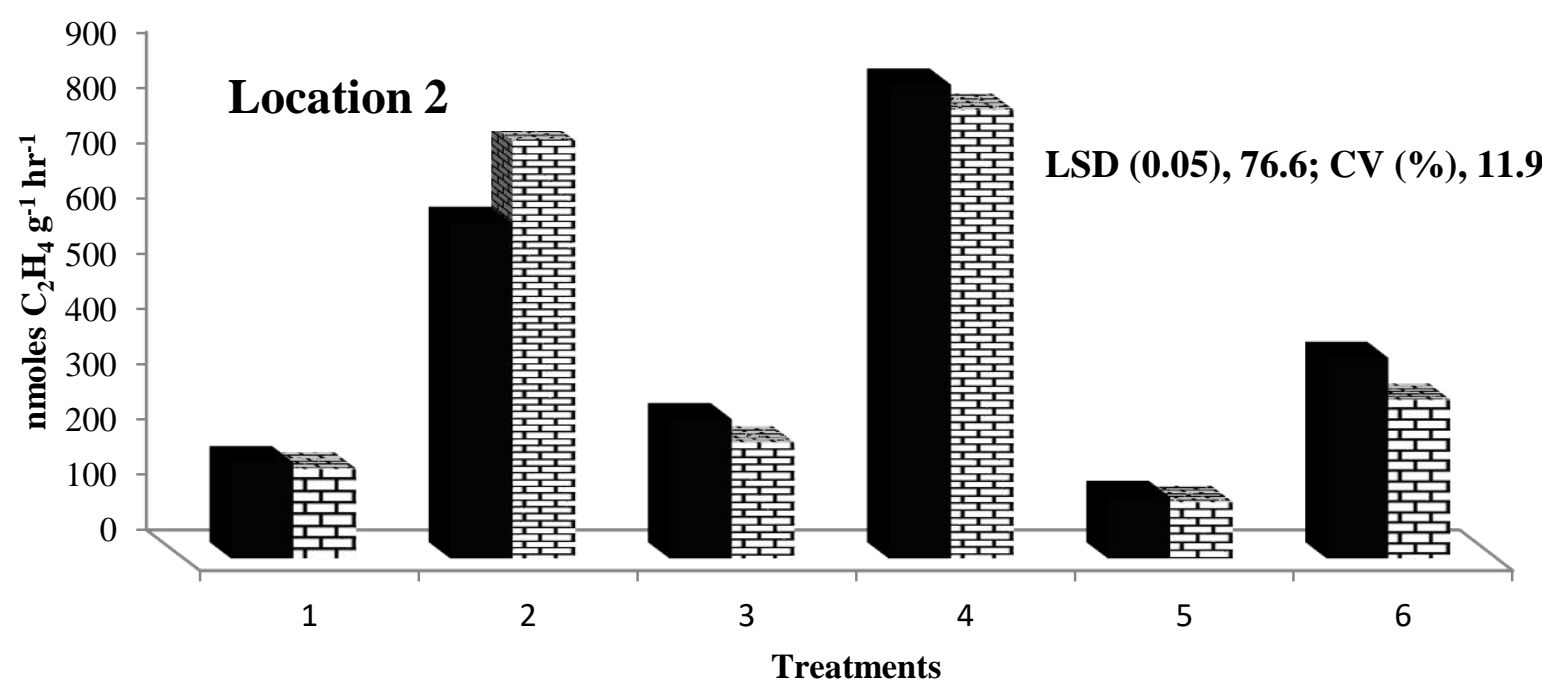

Fig.4: Acetylene reducing activities of soils under wheat cultivation in fallow field and subsequent to peanut as affected by diazotroph inoculation and $\mathrm{N}$ fertilization. 1) uninoculated-unfertilized, 2) inoculated-unfertilized, 3) uninoculated $+50 \mathrm{~kg} \mathrm{~N}$ acre $^{-1}$, 4) inoculated $+50 \mathrm{~kg} \mathrm{Nacre}{ }^{-1}$, 5) uninoculated $+100 \mathrm{~kg} \mathrm{Nacre}^{-1}$ and 6) inoculated $+100 \mathrm{~kg} \mathrm{Nacre}{ }^{-1}$.

Table (3) presents the impacts of associative diazotrophs inoculation, mineral $\mathrm{N}$ supplement and experimental site on growth traits of wheat cultivated in fallow field (control) or subsequent to peanut. Total biological yield of the cereal following the legume was higher compared to control, a finding that scored for treated and untreated non-legume. The highest biomass yield of fallow-cultivated wheat (3.82 $\mathrm{kg} \mathrm{plot}^{-1}$ ) was obtained at location 2 (season 2016-2017) due to associative diazotroph inoculation in combination with $100 \mathrm{~kg} \mathrm{~N}$ acre ${ }^{-1}$. On the contrary, untreated plants produced the lowest yields $\left(<0.73 \mathrm{~kg} \mathrm{plot}^{-1}\right) @$ both experimental sites. In general, dry matter yields of wheat following peanut exceeded those of the fallow by 21.2 and $12.5 \% @$ locations 1 and 2 respectively. Again, soil of location 2 characterized by higher fertility level supported better biological yield ( $c a .31 \%$ ) over the corresponding at site 1. Integrated diazotroph inoculation and $\mathrm{N}$ fertilization resulted in the highest grain production. Simultaneous inoculation and $100 \mathrm{~kg} \mathrm{~N}$ acre ${ }^{-1}$ application produced the superior grain yields particularly at location 2. Again, and apart from treatment, wheat subsequent to peanut yielded $0.25 \mathrm{~kg}_{\text {grains }}$ plot $^{-1}$ more than fallow-cultivated one.

Table.3: Yield parameters of wheat plants subsequent to peanuts as affected by diazotroph inoculation and $N$ fertilization

\begin{tabular}{|c|c|c|c|c|c|c|c|c|}
\hline \multirow[t]{3}{*}{ Treatments } & \multicolumn{4}{|c|}{ Control field (fallow) } & \multicolumn{4}{|c|}{ Subsequent to peanut } \\
\hline & \multirow{2}{*}{$\begin{array}{c}\text { Total } \\
\text { biological } \\
\text { yield } \\
\text { (kg plot }^{-} \\
1 \text { ) }\end{array}$} & \multirow{2}{*}{$\begin{array}{c}\text { Grain } \\
\text { yield } \\
\left(\text { kg plot }^{-1}\right)\end{array}$} & \multicolumn{2}{|c|}{ Protein (\%) } & \multirow{2}{*}{$\begin{array}{c}\text { Total } \\
\text { biological } \\
\text { yield } \\
\left(\mathrm{kg} \mathrm{plot}^{-1}\right)\end{array}$} & \multirow{2}{*}{$\begin{array}{c}\text { Grain } \\
\text { yield } \\
\left(\mathrm{kg} \mathrm{plot}^{-1}\right)\end{array}$} & \multicolumn{2}{|c|}{ Protein $(\%)$} \\
\hline & & & Grain & Straw & & & Grain & Straw \\
\hline \multirow{8}{*}{$\begin{array}{l}\text { Uninoculated-unfertilized } \\
\text { Inoculated-unfertilized } \\
\text { Uninoculated }+50 \mathrm{~kg} \mathrm{~N}^{-1} \text { acre }^{-1} \\
\text { Inoculated }+50 \mathrm{~kg} \mathrm{~N} \text { acre }^{-1} \\
\text { Uninoculated }+100 \mathrm{~kg} \mathrm{~N} \text { acre }^{-} \\
1 \\
\text { Inoculated+100 kg N acre }{ }^{-1}\end{array}$} & \multicolumn{8}{|c|}{ Location $1(2015-2016)$} \\
\hline & 0.73 & 0.32 & 9.3 & 1.8 & 0.86 & 0.33 & 9.8 & 1.7 \\
\hline & 0.94 & 0.41 & 9.6 & 2.4 & 1.24 & 0.40 & 10.4 & 2.6 \\
\hline & 1.32 & 0.64 & 11.2 & 2.6 & 1.66 & 0.81 & 12.1 & 3.0 \\
\hline & 2.66 & 1.24 & 12.4 & 2.9 & 2.83 & 1.46 & 12.9 & 3.6 \\
\hline & 2.82 & 1.36 & 11.3 & 3.3 & 3.81 & 1.42 & 12.9 & 3.9 \\
\hline & 3.13 & 1.41 & 13.3 & 3.6 & 3.61 & 1.93 & 13.2 & 4.1 \\
\hline & & & & & & & & \\
\hline
\end{tabular}




\begin{tabular}{|c|c|c|c|c|c|c|c|c|}
\hline & \multicolumn{8}{|c|}{ Location 2 (2016-2017) } \\
\hline Uninoculated-unfertilized & 0.69 & 0.29 & 8.1 & 2.0 & 0.82 & 0.31 & 8.0 & 1.9 \\
\hline Inoculated-unfertilized & 1.01 & 0.50 & 9.2 & 2.0 & 1.41 & 0.72 & 9.9 & 2.3 \\
\hline Uninoculated $+50 \mathrm{~kg} \mathrm{~N}$ acre $^{-1}$ & 2.69 & 1.00 & 11.9 & 2.8 & 2.92 & 1.42 & 12.8 & 3.6 \\
\hline Inoculated+ 50 kg N acre ${ }^{-1}$ & 3.82 & 1.69 & 13.3 & 3.4 & 4.66 & 1.83 & 13.9 & 4.2 \\
\hline Uninoculated $+100 \mathrm{~kg} \mathrm{~N}^{-}$acre $^{-}$ & 3.71 & 1.54 & 14.1 & 3.7 & 3.88 & 1.89 & 14.0 & 4.0 \\
\hline 1 & 3.90 & 1.88 & 14.0 & 3.4 & 4.11 & 2.72 & 14.8 & 4.6 \\
\hline Inoculated+ $100 \mathrm{~kg} \mathrm{~N}$ acre $^{-1}$ & & & & & & & & \\
\hline
\end{tabular}

The respective LSD $(0.05)$ values for total biological yield, grain yield and protein percentages of grains and straw are $0.21,0.13,0.66$ and 0.41 for location 1 and $0.29,0.22,0.51$ and for location 2 .

Lower quantities of protein were accumulated in wheat straw compared to those in grains, $1.7-4.6 \%$ were estimated for the former against $8.0-14.8 \%$ for the latter. In rotation with the legume, the cereal accumulated higher amounts of $\mathrm{N}$ in its tissues compared to the corresponding cultivated in fallow, with average increase percentages of 5.1 and 16.3 in grains and straw respectively. The effects of diazotroph inoculation and/or $\mathrm{N}$ fertilization were very obvious in this respect.

\section{DISCUSSION}

Several investigators have been dealt with the introduction of leguminous plants into crop rotation systems. This based on the stimulating influence of such crops on yield quality and quantity of the subsequent nonlegume crops. In fact, the advantages or disadvantages of crop rotations between legumes and cereals should be assessed taking into consideration the pairwise comparison among both. Numerous studies focused on multi-year and multi-species rotation patterns provided some knowledge in respect to the growth and yield benefits to the subsequent crop (Campigila et al., 2014; Angus et al., 2015; Stagnari et al., 2017). Preissei et al. (2015) concluded that the agronomic pre-crop advantages of legume crops could be expressed in two major effects. The first is "nitrogen effect" due to nitrogen supply via biologically fixed atmospheric dinitrogen particularly in $\mathrm{N}$ limited situations. The "break crop effect" is the second which represent the benefits to the subsequent non-legume crop due to several factors, those encompass 1) improving soil physicochemical properties and modifying soil structure, 2) increasing soil organic matter content, 3) phosphorus mobilization, 4) retention and availability of water and 5) alleviation of the harmful effects of diseases and weeds. Actually, no much work has been done on the contribution of the "Integrated Fertilizer Management, IFM" on the legume-cereal rotation particularly in stressed environments. This study was carried out, therefore, to present original information on the residual effect of a summer legume (peanut) on a subsequent winter cereal (wheat) as affected by diazotroph inoculation and $\mathrm{N}$ fertilization in sandy soil, characterized by low fertility level and nutrient deficiencies beside drought stress.

Table (4) summarizes the over-all beneficial residual effect of peanut on yield traits of wheat. Regardless the applied treatments, wheat total biological yield increases in residual effect-field over the fallow one were falling in the ranges $6.4-35.1 \%$ and $4.6-38.5 \%$ for experimental locations 1 and 2 respectively. Respective increase percentages of 3.1-26.6 and 6.9-44.7 were estimated for the cereal grain yield. The residual effect reflected, as well, on protein pool of both grains and straw, increases of 4.0-14.2 and 4.5-7.6\% were scored for the former as well as 8.3-24.1 and 8.1-35.3 \% for the latter. These findings indicate that the positively yield turnover of the legume do extend to the succeeding non-legume crop. The positive residual effect of legumes on subsequent non-legumes has been demonstrated in the literature. In this concern, Angus et al. (2015) recorded significantly higher grain yields of wheat when cultivated after either lupine, faba bean, chickpea or lentil compared to those obtained by wheat following wheat. They estimated a yield of 4.0 ton $\mathrm{ha}^{-1}$ for wheat after wheat, against an average of 5.2 ton $\mathrm{ha}^{-1}$ for the cereal following legumes. A vast array of investigations indicated the great dependence of cereal yields following legumes on climatic conditions that strongly affect the dynamics of soil nitrogen. Here, Jensen et al. (2004) reported, in temperate regions, averages of 17 and $21 \%$ higher wheat grain yields in legume-cereal based systems over wheat in fallow in presence of recommend and moderate fertilization regimes respectively. This was not the case in Mediterranean 
Table.4: Change percentages in yield parameters of wheat plants subsequent to peanut (related to those cultivated in fallow field)

\begin{tabular}{|c|c|c|c|c|}
\hline \multirow[t]{3}{*}{ Treatments } & \multirow{2}{*}{$\begin{array}{l}\text { Total biological } \\
\text { yield }\left(\mathrm{kg} \mathrm{plot}^{-1}\right)\end{array}$} & \multirow{2}{*}{$\begin{array}{c}\text { Grain yield } \\
\left(\text { kg plot }^{-1}\right)\end{array}$} & \multicolumn{2}{|c|}{ Protein $(\%)$} \\
\hline & & & Grain & Straw \\
\hline & \multicolumn{4}{|c|}{ Location $1(2015-2016)$} \\
\hline Uninoculated-unfertilized & +17.8 & +3.1 & +5.4 & -5.6 \\
\hline Inoculated-unfertilized & +31.9 & -2.4 & +8.3 & +8.3 \\
\hline Uninoculated $+50 \mathrm{~kg} \mathrm{~N}$ acre $^{-1}$ & +25.8 & +26.6 & +8.0 & +15.4 \\
\hline Inoculated+ $50 \mathrm{~kg} \mathrm{~N}$ acre $^{-1}$ & +6.4 & +17.7 & +4.0 & +24.1 \\
\hline Uninoculated+100 kg N acre ${ }^{-1}$ & +35.1 & +4.4 & +14.2 & +18.2 \\
\hline \multirow[t]{2}{*}{ Inoculated+100 kg N acre ${ }^{-1}$} & +15.3 & +36.9 & -0.8 & +13.9 \\
\hline & \multicolumn{4}{|c|}{ Location 2 (2016-2017) } \\
\hline Uninoculated-unfertilized & +18.8 & +6.9 & -1.2 & -5.0 \\
\hline Inoculated-unfertilized & +38.5 & +44.0 & +7.6 & +15.0 \\
\hline Uninoculated+ $50 \mathrm{~kg} \mathrm{~N}$ acre $^{-1}$ & +8.6 & +42.0 & +7.6 & +28.6 \\
\hline Inoculated+ $50 \mathrm{~kg} \mathrm{~N}$ acre $^{-1}$ & +22.0 & +8.3 & +4.5 & +21.1 \\
\hline Uninoculated+100 kg N acre ${ }^{-1}$ & +4.6 & +22.7 & -0.7 & +8.1 \\
\hline Inoculated+100 kg N acre $^{-1}$ & +5.4 & +44.7 & +5.7 & +35.3 \\
\hline
\end{tabular}

Among the factors that determine the yield advantage of legumes to the subsequent cereals is the quantity of $\mathrm{N}_{2}$ fixed by the introduced diazotrophs (Stagnari et al., 2017). In comparison between 25 groundnut varieties for biological nitrogen fixation @ three various agro-ecologies in South Africa, Mokgehle et al. (2014) found that the amount of $\mathrm{N}_{2}$ fixed ranged from 76 to $188 \mathrm{~kg} \mathrm{ha}{ }^{-1}$ depending upon soil physico-chemical properties and prevailing environmental conditions. Soil stresses such as salinity and alkalinity were reported by Faghire et al. (2013) and Van Zweten et al. (2015) to affect the contribution of legumes, via $\mathrm{N}_{2}$ fixation, to yield benefits of subsequent cereal crops. Additionally, $\mathrm{N}$ supply, in rational rates, supported the beneficial residual effect of legumes to non-legumes (People et al., 2009). In conformity with the previous studies, findings of the present investigation proved the positive impact of both diazotroph inoculation and mineral $\mathrm{N}$ fertilization on wheat yields when cultivated after peanut. Figure (5) illustrates the individual and/or combined effects of inoculation with diazotrophs and $\mathrm{N}$ fertilizer application on the cereal yield traits. This indicates that beside magnifying the biomass, grain and protein yields of the cereal following the legume, the former crop meets some of its $\mathrm{N}$ requirements via rotation with the latter. However, People et al. (2009) emphasized the difficulty of quantification of the $\mathrm{N}$ released from a legume to the following non-legume from that of other sources. Studies of Jeuffroy et al. (2013) revealed that the quantity of nitrate- $\mathrm{N}$ available for wheat plants cultivated after legumes approximated $37 \mathrm{~kg} \mathrm{~N} \mathrm{ha}^{-1}$. Jensen et al. (2004) found that 23-59 \% more $\mathrm{N}$ was up taken by non-legume plants following legumes and only 14-15\% for durum wheat subsequent to vetch. Furthermore, Stagnari and Pisante (2010) mentioned that the residues of some leguminous crops are having beneficial impacts on some quality aspects of the next rotating non-legumes. In addition to the stimulatory effects of $\mathrm{N}_{2}$ fixed and legume residues on the subsequent nonlegumes, Hocking (2001) reported that several grain legumes such as pea, chickpea and white lupine possess the ability to mobilize the fixed forms of phosphorus in soil via releasing the organic acids citric and malic as parts of the root exudates. As mentioned by Kirkegaard and Ryan (2014), the effects of "break crops" encompass increasing soil water content due to their ability to affect the relation of soil and rain water. Production of hydrogen gas $\left(\mathrm{H}_{2}\right)$, as a by-product of $\mathrm{N}_{2}$-fixation, is among the beneficial impacts of legumes to rotating non legumes, since it greatly affects the soil microbiome composition and consequently support the growth and activity of plant growth promoting rhizobacteria (Angus et al., 2015). 


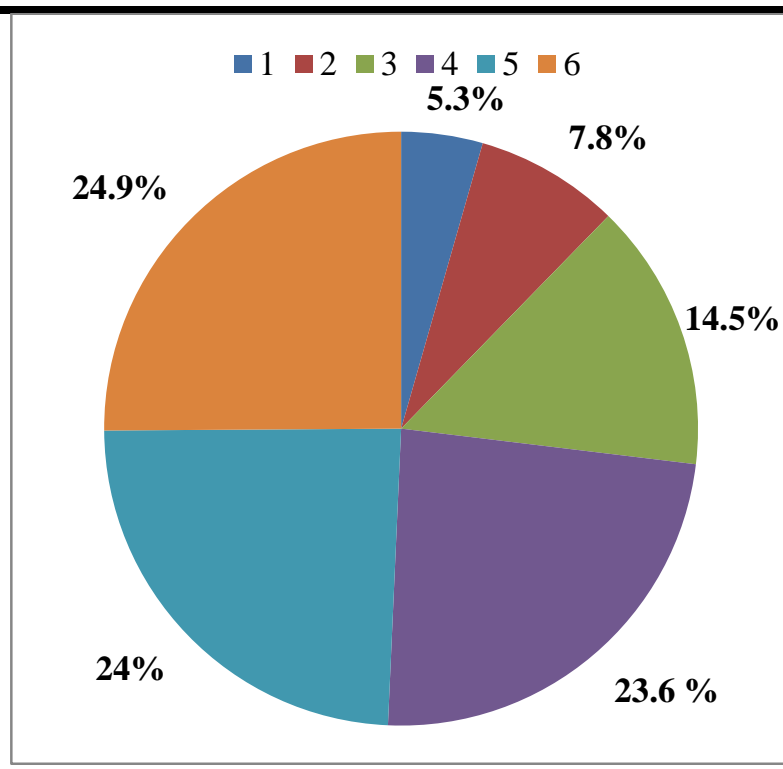

Total biological yield ( $\left.\mathrm{kg} \mathrm{plot}^{-1}\right)$ $\square 1 \square 2 \square 3 \square 4 \square 5 \square 6$

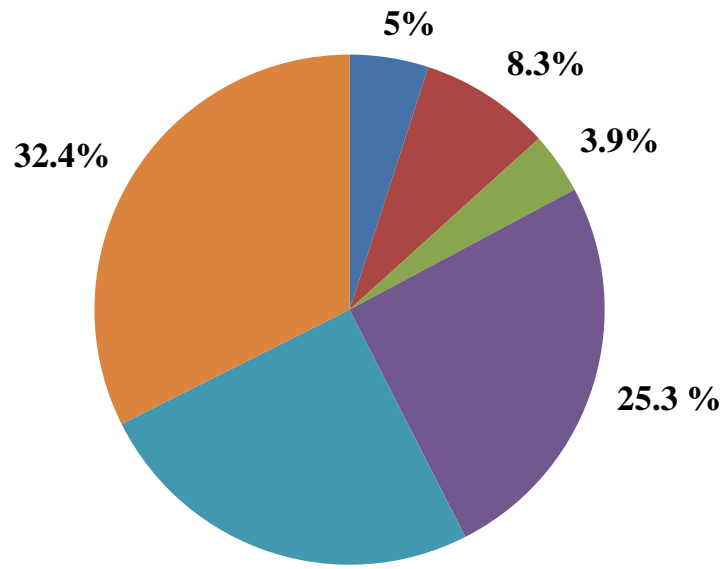

$25.1 \%$ $\square 1 \square 2 \square 3 \square 4 \square 5 \square 6$

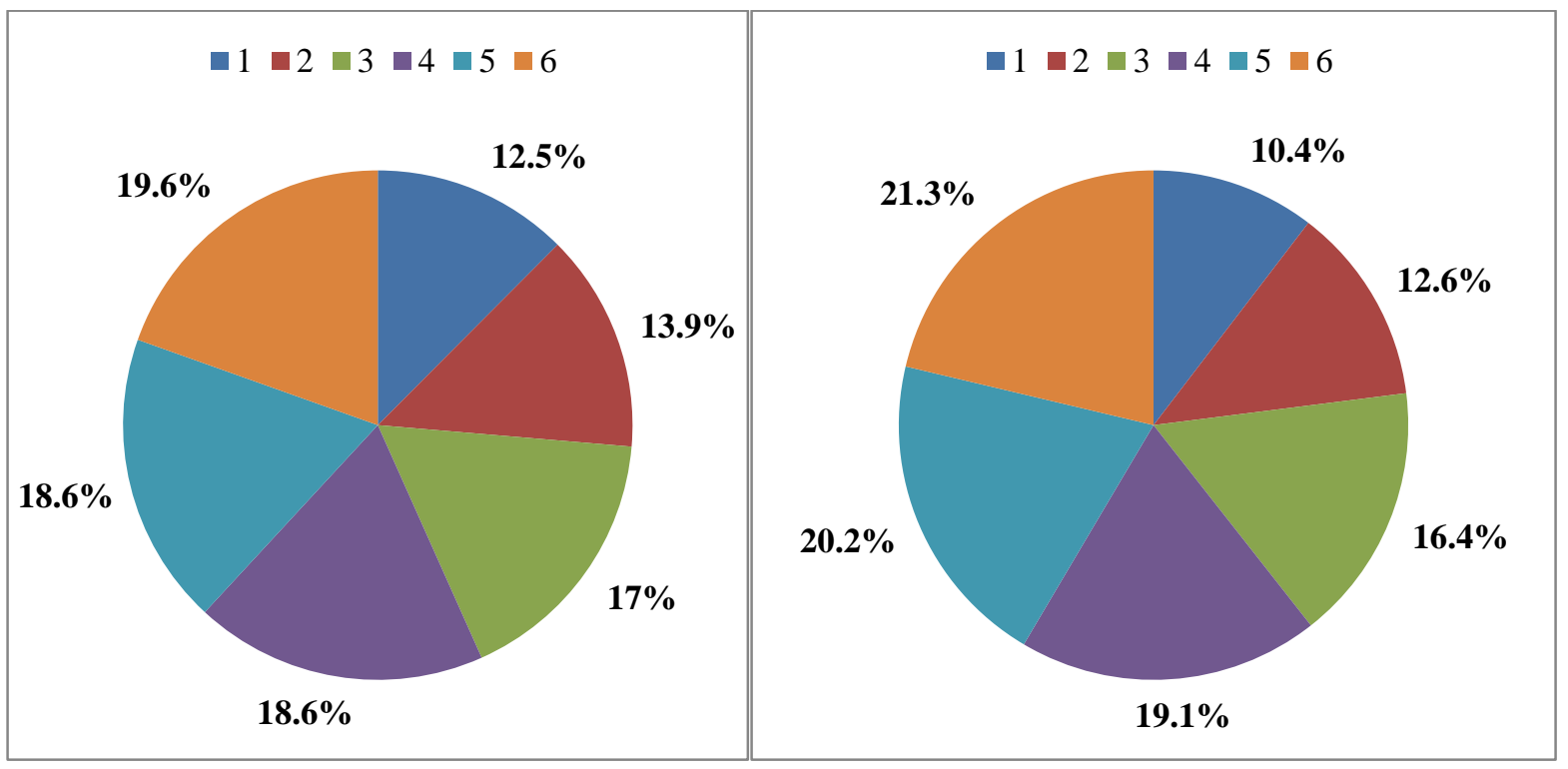

Grain yield $\left(\mathrm{kg} \mathrm{plot}^{-1}\right)$

Grain protein (\%)

Fig.5: Comparative wheat yields attributed to diazotroph inoculation and $N$ fertilization. 1) uninoculated-unfertilized, 2) inoculated-unfertilized, 3) uninoculated $+50 \mathrm{~kg} \mathrm{Nacre}^{-1}$, 4) inoculated $+50 \mathrm{~kg} \mathrm{~N} \mathrm{acre}^{-1}$, 5) uninoculated $+100 \mathrm{~kg} \mathrm{~N} \mathrm{acre} \mathrm{e}^{-1}$ and 6) inoculated $+100 \mathrm{~kg} \mathrm{~N}$ acre $^{-1}$.

\section{CONCLUSION}

Despite the established benefits, several concerns should be addressed to guarantee a successful introduction of legumes into cropping sequences. Such cropping patterns must be controlled by adopting the appropriate management practices including 1) $\mathrm{N}$ fertilizer type, rate and time of application, 2) irrigation regime, 3) biofertilizer type and method of addition, and 4) weed and pest control. Such procedures often do not match those applied by farmers. However, to magnify the benefits of legumecereal rotations, some efforts should be done including adopting breeding programs for improving crop yields for better sustain livelihood and raise the economic return to farmers. From a microbiological point of view, the BNF capability of the used bioformulations must be evaluated and controlled to cope with plant characteristics, soil physico-chemical properties and prevailing environmental conditions. 


\section{REFERENCES}

[1] Angus, J.F.; Kirkegaard, J.A.; Hunt, J.R.; Ryan, M.H.; Ohlander, L. and Peoples, M.B. (2015). Break crops and rotations for wheat. Crop Pasture Sci., 66:523-552.

[2] Badawi, H. Mona. (2014). Diazotroph strain-wheat cultivar affinity guarantees proper cereal yield and soil nitrogen budget. Res. J. Agric. Biol. Sci., 10(1): 8-16.

[3] Bremner, J.M. (1965). Total nitrogen. In: Black, C.A., et al. (eds.), Methods of Soil Analysis. Part 2. Agron. Monogr., ASA, Madison, WI., 9: 1149-1178.

[4] Campiglia, E.; Mancinelli, R.; DiFelice, V. and Radicetti, E. (2014). Long-term residual effects of the management of cover crop biomass on soil nitrogen and yield of endive (Cichorium endivia L) and savoy cabbage (Brassica oleracea var. sabauda). Soil Tillage Res., 139: 1-7.

[5] Chapman, H. D. and Pratt, P. E. (1978). Methods of analysis for soils, plants, and waters. Univ. of Calif., Div. Agric. Sci., Priced Pub., 4034.

[6] Evans, J.; McNeill, A.M.; Unkovich, M.J.; Fettell, N.A. and Heenan, D.P. (2001). Net nitrogen balances for cool-season grain legume crops and contributions to wheat nitrogen uptake: a review. Aust. J. Exp. Agric., 41: 347-359.

[7] Faghire, M.; Mohamed, F.; Taoufiq, K.; Faghire, R.; Bargaz, A. and Mandri, B. (2013). Genotypic variation of nodules'enzymatic activities in symbiotic nitrogen fixation among common bean (Phaseolus vulgaris L.) genotypes grown under salinity constraint. Symbiosis. 60:115-122.

[8] Hayat, R.; Ali, S.; Siddique, M. T. and Chatha, T. H. (2008). Biological nitrogen fixation of summer legumes and their residual effects on subsequent rainfed wheat yield. Pakistan J. Bot., 40(2): 711-712.

[9] Hegazi, N.A., Amer, H.A. and Monib, M. (1980). Studies on $\mathrm{N}_{2}$-fixing spirilla (Azospirillum spp.) in Egyptian soils. Rev. Ecol. Biol. Soil, 17:491-499.

[10] Hocking, P.J. (2001). Organic acids exuded from roots in phosphorus uptake and aluminum tolerance of plants in acid soils. Adv. Agron., 74:63-97.

[11] Huang, L.S. and Chen, J. (2008). Analysis of Variance, Coefficient of Determination and F-Test for Local Polynomial Regression. The Annals of Statistics, 36(5): 2085-2109.

[12] Jensen, C.R.; Joernsgaard, B.; Andersen, M.N.; Christiansen, J.L.; Mogensen, V.O.; Friis, P. and Petersen, C.T. (2004). The effect of lupins as compared with peas and oats on the yield of the subsequent winter barley crop. Eur. J. Agron., 20:405418.

[13] Jensen, E.S.; Peoples, M.B. and HauggaardNielsen, H. (2010). Faba bean in cropping systems. Field Crops Res., 115:203-216.

[14] Jeuffroy, M.H.; Baranger, E.; Carrouée, B.; Chezelles, E.D.;Gosme, M. and Hénault, C. (2013). Nitrous oxide emissions from crop rotations including wheat, oilseed rape and dry peas. Biogeosciences. 10:1787-1797.

[15] Kirkegaard, J.A. and Ryan, M.H. (2014). Magnitude and mechanisms of persistent crop sequence effects on wheat. Field Crops Res., 164:154165.

[16] Köpke, U. and Nemecek, T. (2010). Ecological services of faba bean. Field Crop Res. 115:217-233.

[17] Mohd-Radzman, N.A.; Djordjevic, M. A. and Imin, N. (2013). Nitrogen modulation of legume root architecture signaling pathways involves phytohormones and small regulatory molecules. Front. Plant Sci., 4:385-389.

[18] Mokgehle, S.N.; Dakora, F.D. and Mathews, C. (2014). Variation in $\mathrm{N}_{2}$ fixation and $\mathrm{N}$ contribution by 25 groundnut (Arachis hypogaea L.) varieties grown in different agro-ecologies, measured using ${ }^{15} \mathrm{~N}$ natural abundance. Agric. Eco. Environ., 195:161172.

[19] Peoples, M.B.; Brockwell, J.; Herridge, D.F.; Rochester, I.J.; Alves, B.J.R. and Urquiaga, S. (2009). The contributions of nitrogen-fixing legumes to the productivity of agricultural systems. Symbiosis. 48:1-17.

[20] Peoples, M.B and Herridge, D.F. (1990). Nitrogen fixation by legumes in tropical and subtropical agriculture. Adv. Agron., 44: 155-223.

[21] Preissel, S.; Reckling, M.; Schläfke, N. and Zander, P. (2015). Magnitude and farm economic value of grain legume pre-crop benefits in Europe: a review. Field Crop Res., 175:64-79.

[22] Stagnari, F.; Maggio, A.; Galieni, A. and Pisante, M. (2017). Multiple benefits of legumes for agriculture sustainability: an overview. Chem. Biol. Technol. Agric., 4: 2-13.

[23] Stagnari, F. and Pisante, M. (2010). Managing faba bean residues to enhance the fruit quality of the melon (Cucumis melo L.) Crop, Sci. Hort., 126:317-323.

[24] UNWPP (United Nations World Population Prospects): The 2012 version, key findings and advance tables. Working paper no. ESA/P/WP.227; 
2013 (United Nations, Department of Economic and Social Affairs, Population Division, New York).

[25] Van Zwieten, L.; Rose, T.; Herridge, D.; Kimber, S.; Rust, J.; Cowie, A. and Morris, S. (2015). Enhanced biological $\mathrm{N}_{2}$ fixation and yield of faba bean (Vicia faba L.) in an acid soil following biochar addition: dissection of causal mechanisms. Plant Soil, 395:7-20.

[26] Westhoek, H.; Rood, T.; van den Berg, M.; Janse, J.; Nijdam, D.; Reudink, M. and Stehfest, E. (2011). The protein puzzle. The consumption and production of meat, dairy and fish in the European Union. Nether. Environ. Assess. Age., (PBL).

[27] Zou, L.; Yli-Halla, M.; Stoddard, F. and Mäkelä, P. (2015). Effects of break crops on yield and grain protein concentration of barley in a boreal climate. PLOS ONE |DOI:10.1371/journal.pone, 1-13. 